\title{
VIOLATION OF CONVERSATION RULES IN TURN TAKING IN THE SECOND STEP CLASS AT CEC MATARAM
}

\author{
Roy Armansyah' ${ }^{1}$ Asbah $^{2}$, Moh. Fauzi Bafadal ${ }^{3}$ \\ 1,2,3Pendidikan Bahasa Inggris, Universitas Muhammadiyah Mataram, royarmansyah95@gmail.com
}

\section{INFO ARTIKEL}

Riwayat Artikel:

Diterima: 03-02-2018

Disetujui: 05-03-2018

\section{Key Word: \\ Turn Taking \\ Conversation}

\begin{abstract}
Abstract: Turn taking is simplest systematic for the organization of turn taking for conversation (Sacks, Schegloff, and Jefferson (1974). In conversation, sometimes the participant violate the rules as they begin to talk, meanwhile the other speakers are still speaking, and none of words and sentences to say in turn. Therefore, the writer was interested to analyze the violation of conversation rules in turn taking in order to investigate kinds of violation of conversation rules in turn taking that happened in the second step class of CEC Mataram, especially in debating activity by using a descriptive qualitative design. Then, the data were collected through video-recording from the second step class members of CEC Mataram. They were about 65 students and one teacher. Based on finding of this study, the writer found out five violations, such as violation of pause, gaps, laps, overlaps, and interruption. The first highest violation was pause violation with 135 times (81.3\%) implies that the speaker in debating activity was silence within the turn given. The second one was interruption with 15 times (9.1\%) implies that the other speakers began to talk when a speaker was speaking. The third was overlaps with 7 times (4.2\%) implies that the speaker spoke at same time. The fourth was gaps with 5 times (3.0\%) implies that the speaker did not talk directly when other speaker were given a chance to turn when one speaker was replaced. The fifth was laps with 4 times (2.4\%) implies than none options for next turn is used when speaker change, the participant did not indicate backchannel during the debating activity ( $0 \%$ of violation).
\end{abstract}

\section{A. BACKGROUND OF THE STUDY}

Conversation is an activity where people talk to each other, and deliver information, and share the massages. The conversation usually involves at least two peoples or more to make the conversation comes true. The conversation, actually has it's own law and order where someone can give the opinion with the way that suppose to, but as matter of fact, we often find out people speak as they want although it was not their chance to speak.

In conversation analysis (CA) there is a so called turn taking system that one ussualy discusses. Turn taking is a rule that manage conversation how participant change when the turn given. According to, Goodwin (1981) said that turn taking in linguistic can be defined as "the process through which the party doing talk at the moment is changed". in addition, Sacks, Schegloff, and Jefferson (1974) said that turn taking is simplest systematic for the organization of turn taking for conversation. Violation of conversation that happen in turn taking show up when speaker disturbs the other speaker says, and the other speaker is does not know what they have to say. Kinds of violation that happen are interruption, overlaps, backchannel, silence(gaps, laps, and pause). For example, when the speaker begin to talk, the other one must wait until the othe speaker has finished his/her turn and the speaker may speak if she/he gets opportunity to speak.

There are some previous studies about violation of conversation in turn taking that support this research, the first"The Realization of Turn Taking System in Lawan Bicara Debat a METROTV Program Broadcasted on $13^{\text {th }}$ January 2014" by Fitri Amalia Sinta Siwi. In this research, the writer found out some violations that happen during analyzing the program, and it show up are pause, interruption, and overlaps. The Second, "Conversational Analysis of Turn Taking Behavior and Gender Differences in Multimodal Conversation on December 2015" by Shazia Akbar Ghilzai. In this study, the writer observe if female more dominant in conversation than male.

The third, "Conversation Analysis of the Interview between Oprah Winfrey and the founder of Facebook Mark Zuckerberg on 15 thAugust 2012" by Putra Gigih 
Pamungkas. In this research that made by Putra Gigih Pamungkas about turn taking in conversation, the researcher did not find turn taking violation in conversation, it proved by the data that researcher obtained turn taking was running normal.

From explanation above, it is possible to the speaker violate conversation during the turn taking, therefore the researcher was interested to discuss about violation of conversation rules in turn taking of CEC Mataram due to the following reasons. The first, are to avoid violation of conversation that happen during speaker give the turn. The Second, give the insight about how the speaker take the opportunity to speak based on the rule and the third, to give the knowledge about violation that happen in conversation.

\section{B. RESEARCH METHOD}

In this study the writer used a case study and descriptive qualitative design. Descriptive qualitative design is used for describing situation or events (Isaac and Michael, 1987:91) (Coulthard. 2012). It is to analyze violation of conversation rules in turn taking in the second step class of CEC Mataram.

The data were collected by using observation checklist, where the researcher did observation first, then used video recording to take the data. Location of research is at CEC in Punia jln. ABD Kadir Munsyi Mataram in front of SMPN 9 Mataram. The participant are members of the second step class of CEC English course Mataram. the Participants were consisting of 65 students and one teacher.

\section{FINDING}

TABLE 1

VIOLATION OF CONVERSATION RULES IN TURN TAKING IN THE SECOND STEP CLASS OF CEC MATARAM

\begin{tabular}{|c|l|c|c|c|}
\hline No & \multicolumn{2}{|c|}{$\begin{array}{c}\text { Violation of } \\
\text { Conversation Rules in } \\
\text { Turn Taking }\end{array}$} & Time & Percentage \\
\hline 1 & Silence & Pause & $\begin{array}{c}135 \\
\text { Times }\end{array}$ & $81.3 \%$ \\
\hline 2 & & Gaps & 5 Times & $3.0 \%$ \\
\hline 3 & & Laps & 4 Times & $2.4 \%$ \\
\hline 4 & Overlaps & 7 Times & $4.2 \%$ \\
\hline 5 & Interruption & 15 Times & $9.1 \%$ \\
\hline 6 & Backchannel & 0 & 0 \\
\hline \multicolumn{3}{|c|}{ TOTAL } & 166 & $100 \%$ \\
\hline
\end{tabular}

Based on the table above, violation of conversation rules in turn taking that is categorize as highest was Pause 135 times (81.3\%). Violation that participant often did during debating activity was in giving opinion. The second violation that happened was interruption, the occurred of violation of interruption was about 15 times $(9.1 \%)$ that participant did. The third was violation of overlaps, they appeared about 7 times (4.2\%) that appear in debating activity at second step. The fourth violation that happened was gaps, they appear about 5 times (3.0\%) when speaker was changed. The next kinds was laps, they appeared was about 4 times (2.4\%) when speaker changed to take the turn. In the last, the violation that nothing happened was backchannel (0\%).

\section{DISCUSSION}

\section{Example of Pause (P).}

According to Sacks et al. (1974) Pause is silence within the turn. It happened when speaker gave the turn and appeared by same speaker. This one happened when speaker faced difficult word or forgot the thing to say

1. When Awan said: "ok now tell story yaa, Village between village or city is same ya, but it's only differenciate by education, association, and dan what else ..... (p) hospital and then education. : please stand up in the middle please face to .......(p), Yaa and explain your opinion". The moment when Awan keep the silence within his statement... and dan what else...(p)... and please stand up in the middle please face to ...(p) was categorized as pause because he did silence when he was given the turn. It appeared because he did not know what he had to say and his difficulties in vocabulary and the behaviour of participant did not followed the instruction.

2. When Ilham after did self-selection and he said "because in village something not easy, kubam in is business is not easy (is easier: Awan) yaa is easier, because in city you get ..... (p) I mean it's for easy for get the .....(p)customer in city." The moment when lham silent within the turn between his statement ... because in city you get ...(p) I mean, and .... it's for easy for get the .....(p)... customer in city... was categorized as pause because when he delivered the opinion he did not know what he had to say, and difficult to say the appropriate word that's way he stooped a second within the turn.

3. When Ulfaidah did self-selection, she said "a pleace in village we can aa always enjoy and always peace and we can live with kindness if we live in city there is ......(p) there are so many conflict and there always crowded maybe and aaa....if .......(p) if in village aaa we can life in aa comfortable. Ok that's all". The moment when Ulfaidah keep in silent between her statement... there is...(p)... was categorized as pause because when she delivered the turn he did not know what she had to say or difficult to give explanation, that's way he stopped a second within the turn.

4. When Awan selected next speaker, he choosed Lia and she said "ok $i$ want to deny about your opinion aaaa the first you said if in.....(p) village we can live enjoy yes always enjoy. $i$ think no, because aaaa in village in village also aaaa crowded also like .......(p) city and than you said there is aaaa you said ........(p) 
maybe that's mean you don't believe with your opinion because you said maybe yes and then aaaa about the comfortable aaaa in city you can live comfortable also and $i$ think more comfortable in city than ......(p) village, why i said like that, because in the city now aaaa if you look for......(p) if you look for......(p) hospital you can find quickly and you about education there are many choice if you want to .....(p) aaaa there are many choices if you want to aaa study or other and then in city you can find fastly like aaaa what else .....(p) wait wait like hospital, education, and then office aaaaa $i$ mean office about .....(p) your.....(p) daily activity your activity like aaaa police office, and then aaaa post office and aaaaaP like that, why $i$ say in city more comfortable than ......(p) village because aaaaa.....(p) what else.....(p) wait wait .......(p) the maen point in city you can find aaaaa what ....(p) do you want fastly and then can make live become comfortable. Maybe that's all from me thank you, the last ass war wab. The moment when Lia keep in silent within the turn and she statement ... the first you said if in...(p)... then ... crowded also like...(p) and ... what else.....(p)... was categorized as pause because it happened in same speaker, and it happened within she gave the turn, and she found difficult word and forgot what she had to say within the turn.

5. When Albi took the turn from Mr. ABD, he said "Ass. War. Wab.....(p). iaaaaaa disagree, $i$ wanna disagree your opinion (Mr. Awan: I disagree) i disagree with your opinion you say aaaa you you easy you get easy to get rice in....(p). in....P city, but before you easy get rice in city aa you must report in village because aa yes there is no aaa you must someone from city before reach in village and you said aaa you said (applause screaming).....(p), and foreigner always go up there...... (p) so many there are foreigner look for aa village to enjoy and if you wanna enjoy so many place in village aaa so many place in village you must look for in there (Applause ... p) in city there is mall yess mall $i$ know that there is place for have fun but if gotta visit to village so many place for holiday. Maybe that's all from me".The moment when Albi keep in silence within he's opinion "Ass. War. Wab....(.p). iaaaaaa disagree, $i$ wanna disagree your opinion (Mr. Awan: I disagree) i disagree with your opinion you say aaa you you easy you get easy to get rice in....(p). in....(p) city, but before you easy get rice in city aaa you must report in village because aaa yes there is no aaa you must someone from city before reach in village and you said aaa you said ( applause screaming)....(p), was categorized as pause, because he silence within he gave the turn, when he gave the opinion he found difficult word to say and without said anything, and he continue he the turn when applause was over it was also Pause, because he stop the turn because there was applause in middle of turn.

6. When Aini said : "Ok, Ass.War.Wab ok i listen you aaa i listen you in the city if you stay in the city so very crowded yes like that, $i$ disagree with you opinion because you know if you.. aaaaa drunk in the village all of the people can know about your wrong because all the people just like GOSIP you know, and if you just stay in the city .....(p) you can be part success because so many aaa all of the people aa in the city come forward go to city just look for job (applause.....(p) and the second said aaa in the village aaa so many rice you send go to the city and then .....(p) you say agree with us the village so need the city, because there is city get so much money ........ (p) in my opinion if you stay in the city you can think about the rational but if you just stay in village you just think irrational but if you stay in city you think rational and you can't waste your time but you just time is money and you can aaaaaa get so much money if you stay in the kota in the city (applause ......(p) you said the place for holiday but $i$ don't i disagree with your opinion because in the city so many place for holiday for example, the beach, mall, the shop, and then in the city in the city you get so many facility for example in Islamic centre just not only in the village you can get in the city and you can look at that good the most so much kubah aaaa in Islamic centre you can get so many aaaa......(p) you can just get in the city, if you just stay in the......(p) a village you can't be success because aaaa ...(p) there is no ......(p) fasilitas for facility you can't be success but in city you can get it so easy man (applause......(p) ok thank's. it was categorized as pause". The moment when Aini silent within the statement ... in the city .....(p) you can be part success because so many aaa all of the people aaa in the city come forward go to city just look for job (applause.....(p) and the second said aaa in the village aaaa so many rice you send go to the city and then .....(p) was categorized as Pause, why it was categorized pause, because she was silence within she gave the turn or the opinion. It was appeared within the turn because she try to find appropriate word to say and she was thinking about it, that's way pause was appear in the turn and it happened in same speaker, and the other one because of applause from the audience.

\section{Example of Gaps (G)}

According to Sacks et al. (1974). Gaps is silence between the turn. Gaps occur between turn, after turn to talk or after current speaker select the next speaker, and when the next speaker sel- 1 -...-elf (self-selection) when speaker changed. 33

1. When Ilham did s $\epsilon$ on to take the turn after Awan gave the tu.... ...vul said "ok Ilham. please stand up and Ilham respond ............(g) and Awan said please stand up in the middle please face to Yaa and explain your opinion. "The moment when silent between the turn after.Awansaid "okIlham. please stand up and Mr. Ilham respond ..(g) was categorized as Gaps, because Ilham did not take the turn directly, but he was looking like walking around and he has taken the turn by self-selection 
it supposed to be the turn was belong for him but he did not talk which means delay the turn, and it was happening after place to talk (Awan gave the turn) that was Gaps. Gaps happened between Awan's turn and Ilham's turn after Awan in place to talk, also when the speaker is changed.

2. When Awan said "Ok, additional additional Ms. Yaa come on. And Ms. Ika said (G) (Awan: ok Ika please) Bismillahhirrohmannirrohim Ass. War. Wab.aaaa i permission to stand up in front of you ok $i$ want to deny aaaa about aaaa opinion". The moment when silent happened between turn after Awan said "Ok, additional additional Ms. Yaa come on. And Ika said (G) (Awan: ok Ika please) was categorized as gaps because she delayed the turn and did not take the turn directly when place to talk for her and it happened because of she was not ready yet to deliver the opinion in the place to talk, that's way she was discussing to her friend first before giving the turn. Gaps occur when speaker changed and after place to talk that was gaps.

3. When Awan said "Ok so from opponent saya tunjuk aja please Vira stand up and explain your opinion and Vira said ........... (g) (listen your friend guys Awan said) last time you said your live in your." The moment when Awan said and silent between the turn "Ok so from opponent saya tunjuk aja please Vira stand up and explain your opinion and Vira said ........... (g) (listen your friend guys Awan said) last time you said your live in your." was categorized as Gaps why gaps because she did not take the turn directly while Awan has given the turn and she delayed the turn that was laps, how was it happened because she was not ready yet to give the opinion then there was doubt,skeptical,and did not has intention to speak to take the turn that's way gaps appear.

4. The last was Gaps happened to hari. When Hari did self-selection to take the place he said :".......(g) Ass. War. Wab before i make aa conclusion aaaaa". That was gaps why it categorized as gaps because when he had place, he did not talk in the middle, but he shake the hand with Mr. Pandu before started the turn automatically that was delay the turn and gaps can assess when speaker change after place to talk.

\section{Example of Laps (L)}

According to Sacks ( 1974) laps is referred to silence between turn. At turn if current speaker stops and none of options for next turn is used there is a laps.

1. When Awan said "please one person from citizen and stand up and please explain your opinion. Awan count $1 \ldots 2 \ldots 3 \ldots$ (I)". It was categorized as laps because no body took the turn from city side when speaker changed after Awan turn. if speaker stops and none of options for next turn is used and where none of options to speak has been employed that is laps. This is explanation in line with situation that happened because none of options to speak is used before. Ilham did selfselection.

2. When Awan said."Ok next from villager please one person stand up and please explain your opinion. Helmi you want to?Awan count $1 \ldots 2 \ldots 3 \ldots(L)$ ". It was laps because no $b 36$ the options that Mr. Awan gave to the $\mathrm{f} \quad \mathrm{it}$, and continuance of talk was discontinuous because the doubt and not confidence when took the turn beforeUlfaidah took the turn by self-selection. It happened when speaker changed

3. When Awan said "additional please, who want to stand up .......(I) (in city side)."

4. When Awan said "Ok tanggapan dari villager yang lain ..........(I) ok Ms. Otong". Number 3 and 4 was categorized as laps because no body took it when Awan gave the place to talk, because laps is longer silence when speaker changed into taking the place to talk beforeOtong and Ulfaidah selfselection. Why it was happening, because participant form village side was not confidance and was not ready yet when took the turn that teacher gave.

\section{Example of Overlaps (0).}

Violation of overlaps happened when two speaker going on at same time, another word two speaker did not want to heard what the other speaker said. According to Schegloff (2000:7) overlap and simultaneous talk are equivalent terms that refer to talk by more then one speaker at a time.

When Ilham gave the turn he said "Ass. War. W(Verdi: hey Good job pak D good luck, (o).......)". The moment when Ilham said "Assalamualikum Warrahmatullahi $W$ suddenly (Verdi: hey Good job pak D good luck, (o).......)" was categorized as overlaps because when first speaker still talk suddenly the other speaker start to talk so two voices are going on at same time. It happened because they thought they are friend and, it does not disturb the turn so they thought it was fine to do.

\section{Example of Interruption (I).}

According to Jefferson (1983: 6) interruption is the starting up in the midts of another turn talk not letting the other finish. The next speaker begins to speak while the speaker is still speaking.

Rizal said.

Assalamualaikum

"Bismillahhirohmannirohim WarahmatullahiWabarakatuh 
( Ok now, before you explain prepare your conclusion from here. (i). It was categorized as interruption, when the speaker still talking, the other speaker starting with another turn talk and made the first speaker stop the turn with another word not letting the other finish the turn that was interruption. Why did it appear, because too much opinion that the speaker gave, made joking each other and justify the sentences which means to take turn.

\section{E. CONCLUSSION AND SUGGESTION}

\section{Conclussion}

To some up, there were violation of conversation rules that appeared in turn taking in second step class of CEC Mataram and kinds of violation of conversation that appeared was five from six violation that. They are pause, gaps, laps, overlaps, and interruption. Violation of pause achieve the highest violation with 135 times $(81.3 \%)$. It happened when speaker gave the turn or within the turn. The Second is violation of interruption with 15 times with percentage (9.1\%). It happened when the other speaker talk while the other speaker still talk or not letting the other finish. The third is violation of overlaps with 7 times (4.2\%). It happened when two voices going on at the same time. The fourth is violation of gaps with 5 times (3.0\%). It is happened when speaker changed to take place after place to talk. The fifth is violation of laps with 4 times (2.4\%). It is same with gaps when speaker changed, but none option for next turn is used. The last is violation of backchannel. It is nothing happened during debating class, there is no indicate happened.

\section{Suggestion}

a. For teacher, they have to understand and know how to split the time when and how to distribute the chance for the active students in order is not always be dominant in class.

b. For students, in order to comprehend social interaction that happened in classroom and understand turn position when to take the role in discussion.

\section{Acknowledgement}

The writer would like to thanks to Mr. Asbah, M.Hum as first consultant and Mr. Moh. Fauzi Bafadal, M. Pd as second consultant that always give guidance, advising, and motivation to the researcher until this research has done well. Then, the researcher would like to say thank's for Hidayati, M.Hum and Humaira, M. Pd as my examiner that has given some correction and revision in researcher thesis.

\section{REFERENCES}

[1] Arikunto, s, Prosedur Penelitian Suatu Pendekatan Praktik, PT. Rineka Cipta, Jakarta, 2013.

[2] Humaira., "Different Interpretation of Ambiguities Sentences (A Study of Class $C$ The Second Semester Postgraduate Students Majoring English of State University of Semarang), September, 2015.

[3] Hidayati, Asbah, Agung A, The Semantics Study of English Slang used in the Column Cosmo Megazine. September, 2013

[4] Hidayati, Rusnaini. The Use of Semantic Mapping to Increase Students Vocabulary at The Second Grade students of SMPN 9 Mataram in Academic Year 2014/2015. September 2016

[5] Hijril, ismail. Improving Students Speaking Skill Through Conversation. April,2014

\section{The Researcher Profile}

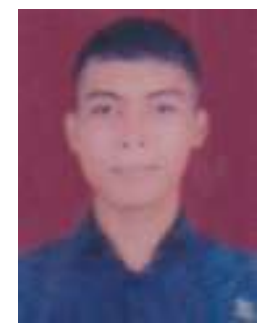

The writer is "Roy Armansyah". Was born on Dompu, 4 march 1995. The writer is the fifth children of five people. Elementary School was began from SDN 11 Manggelewa on years 2003-2007. After that, was continued at SMPN 1 Manggelewa of years 2007-2010 and the last at SMAN 1 Manggelewa of years 2010-2013. Then, the researcher was continued at Muhammadiyah University of Mataram in English Education Program FKIP UM Mataram on 2013. Suggestion and criticism or the improvement of this research that has connection with my journal you can be sent it via e-mail in : royarmansyah95@gmail.com. 